CSDM Views 35

\title{
Defence-Industrial Cooperation with Foreign Countries: Best Practices of Ethics
}

\author{
Todor Tagarev
}

Director, Bulgarian Defence Institute

Associate Senior Fellow, DCAF 
Todor Tagarev, Defence-Industrial Cooperation with Foreign Countries: Best Practices of Ethics

Abstract: In a presentation to the conference on "Security Sector Governance: Defence Production, Sales and Acquisitions" in Kyiv, Ukraine, the author aims to raise the awareness among Ukrainian stakeholders on existing policies, standards, and good practices in corporate ethics of defence companies. The paper outlines key considerations in establishing defence-industrial cooperation across borders and the principles of business ethics. Then it provides examples from the most recent "Company Index" of Transparency International and concludes by emphasising ethical behaviour as a key pre-condition for solid defence industrial cooperation.

Keywords: defence industry, defence procurement, integrity policy, code of ethics, Ukraine

\section{Тодор Тагарев, Отбранително-индустриално сътрудничество с чуждестранни компании: Добри етични практики}

Резюме: В доклада си на конференцията „Добро управление на сектора за сигурност: производство, търговия и придобиване на отбранителни продукти“ в Киев, Украйна, авторът запознава заинтересованите украински представители съществуващи политики, стандарти и добри практики за корпоративна етика на фрирми от отбранителната индустрия. Докладът представя основни съображения в установяването на трансгранично отбранителноиндустриално сътрудничество и принципите на бизнес етиката, дава примери от последния „Фирмен индекс“ на „Прозрачност без граници“. В заключението се подчертава, че етичното поведение е основно предварително условие за стабилно отбранително-индустриално сътрудничество.

Ключови думи: отбранителна индустрия, доставки за отбраната, политика за интегритет, етичен кодекс, Украйна 


\section{INTRODUCTION}

In the decades after the end of the Cold War we witnessed a fundamental reshaping of the defence industries of all leading countries. Both shrinking domestic markets and rapid technological advancements had a role to play. Mergers reduced dramatically the number of main defence contractors, or primes, while in the process of globalisation these primes had the opportunity, and many used it, to pursue global presence.

On the other hand, sound economic interests, along with security of supply considerations, found a political expression in government's requests to relate major defence procurements to offset or similar cooperation programmes leading, in many cases, to integration of smaller industries into the supply chains of primes. This paper briefly introduces the main considerations in crossborder defence industrial cooperation and then focuses on one often neglected dimension of such cooperation - the issue of ethics. It outlines ethical standards and integrity policies of leading defence industrial associations. In conclusion, we underscore the role of integrity and ethics as a key prerequisite for cross-border defence industrial cooperation.

\section{KEY CONSIDERATIONS IN DEFENCE INDUSTRIAL COOPERATION}

The end of the Cold War brought significantly reduced demand for defence products, globally, and triggered a process of acquisitions and mergers, that characterized the defence industrial landscape in the 1990 s and beyond. ${ }^{1}$ The number of main defence contractors, or primes, came down considerably, while the market opportunities they were pursuing expanded. Many clients, on the other hand, demanded offset (or similar) arrangements that in turn facilitated the expansion of the geographical base of suppliers, with supply chains crossing national boundaries.

Political considerations and legal requirements may facilitate defence industrial cooperation, e.g. the inclusion of a company in the supply chain of a prime. Sustainable relations, however, are based on two main factors:

- $\quad$ the competitive advantages of the cooperating companies; and

- $\quad$ trust.

The latter factor accounts for, inter alia, compliance with anti-bribery norms, so that the risks of reputational and legal damages of the improper behaviour of a partner in the supply chain, e.g. an intermediary, are reduced to a minimum. This aspect is examined in the remaining sections of this paper.

1 For overviews of the developments in Europe and the US see respectively Burkard Schmitt, From Cooperation to Integration: Defence and Aerospace Industries in Europe, Chaillot Papers 40 (2000); and Gerald I. Susman and Sean O'Keefe, eds., The Defense Industry in the Post-Cold War Era: Technology, Innovation, Entrepreneurship and Competitive Strategy (Bingley, UK: Emerald Group, 1998). 


\section{CODES OF ETHICS IN THE DEFENCE INDUSTRY}

To reduce the vulnerabilities and provide a "level playing field" on the international markets, ${ }^{2}$ Western defence companies and their associations have set in place a set of policies and standards aiming to free the defence market from corruptive practices. Salient among these are:

- The Global principles of business ethics for the Aerospace and Defence Industry, developed jointly by the Aerospace Industries Association of America (AIA) and AeroSpace and Defence Industries Association of Europe (ASD); and

- The European Common Industry Standards for the prevention of corruption in the Aerospace and Defence sector, set by ASD.

The key underlying principles of business ethics are:

- Each company has an explicit integrity policy;

- $\quad$ There are procedures in place to make company personnel aware of this integrity policy and the demand to comply with it;

- The leadership encourages reporting of improper behaviour and provides appropriate reporting channels;

- Sanctions for such behaviour are also appropriate, proportionate and dissuasive;

- Payments, gifts, political contributions, and charitable donations shall be duly accounted for and traceable;

- There are internal control procedures that provide for enforcement of the integrity policy;

- The principles of the company's integrity policy apply as well to business partners, including advisors, majority-owned joint venture entities, subcontractors and suppliers;

- $\quad$ Conflicts of interest are properly managed;

- Proprietary information is adequately respected.

The standards clearly define the cases when rules of fairness are broken by seeking "improper advantage," a term described in a comprehensive manner:

Companies will not offer, promise, or provide any undue pecuniary or other advantage (e.g. payments, gifts, hospitality, as well as political contributions or charitable donations), to public officials, political parties or political candidates, or to any private party, in order to obtain or retain business or gain any other improper advantage in the conduct of their business. ${ }^{3}$

The common industry standards also envision:

- Compliance with laws and regulations;

- $\quad$ Largest possible scope of application;

- Prohibition of corruptive practices,

and provide guidance in regard to:

2 Competitive conditions, allowing all participants in the international market to compete on an equal and fair basis.

3 Global principles of business ethics for the Aerospace and Defence Industry, $2^{\text {nd }}$ issue (October 2009), p. 2. 
- Gifts and hospitality;

- Political donations and contributions;

- Business partners (due diligence; legal provisions; agreement; fees to intermediaries; verification programmes);

- The design and implementation of integrity programmes;

- Sanctions.

Many defence companies already have well established integrity policies and ethics' codes, and mechanisms for their enforcement. The NATO-DCAF Compendium of best practices in building integrity and reducing corruption in defence outlines good practices in the institutionalization of integrity policies of leading defence companies. ${ }^{4}$

\section{DEFENCE COMPANIES' INTEGRITY INDEX}

In the beginning of the current decade, the UK branch of Transparency International (TI) started monitoring the levels of corruption risks associated with the functioning of defence companies from around the world. ${ }^{5}$ TI-UK uses a methodology looking into five groups of criteria, as follows:

- Leadership, governance, and organisation;

- $\quad$ Risk management;

- $\quad$ Policies \& codes;

- Training; and

- Personnel and helplines. ${ }^{6}$

In its assessments, TI-UK asks respondents to address 41 questions, using a respective set of model answers. Their views are then complemented by evidence from publicly available information, company reviews, internal information and external peer review.

TI-UK published the first integrity index in 2012. The current, 2015 Company Index covers 163 companies, grouped in six clusters from A to $F$, respectively from lowest to highest corruption risks. The Ukrainian companies covered fit into group $F$, that is, as facing highest corruption risks.

\footnotetext{
$4 \quad$ Alice Eldridge, Dominique Lamoureux, and Todor Tagarev, "The Defence Industry as an Ally in Reducing Corruption," in Building Integrity and Reducing Corruption in Defence: A Compendium of Best Practices (Geneva: DCAF, 2010), 250-260, https://defenceintegrity.eu/en/publication/defence-industry-allyreducing-corruption.

$5 \quad$ http://companies.defenceindex.org.

$6 \quad$ Defence Companies' Integrity Index (Cl) 2015 (London: Transparency International-UK Defence and Security Programme, 2015).
} 
In conclusion, I would like to emphasise once again that ethical corporate behaviour is not just a desirable addition to what companies do, and are, but in fact is a pre-condition for solid defence industrial cooperation with Western defence companies. In that respect, this paper aimed to raise the awareness among interested stakeholders and provided examples on existing policies, standards, and good practices in corporate ethics of defence companies. Implementing these principles by Ukrainian defence companies, even in a basic manner, would facilitate the movement up the TI Company Index's ladder and make them more attractive for technological and industrial cooperation with leading Western corporations.

\section{REFERENCES}

Susman, Gerald I., and Sean O'Keefe, eds., The Defense Industry in the Post-Cold War Era: Technology, Innovation, Entrepreneurship and Competitive Strategy. Bingley, UK: Emerald Group, 1998.

Schmitt, Burkard. From Cooperation to Integration: Defence and Aerospace Industries in Europe, Chaillot Papers 40 (2000).

Aerospace Industries Association of America (AIA) and AeroSpace and Defence Industries Association of Europe, Global principles of business ethics for the Aerospace and Defence Industry, Issue 2 (Arlington, VA \& Brussels, October 2009).

AeroSpace and Defence Industries Association of Europe, European Common Industry Standards for the prevention of corruption in the Aerospace and Defence sector, Release \# 2 (Brussels, June 2012).

Defence Companies Anti-Corruption Index (CI) -2015, TI Defence and Security Programme. London: Transparency International UK, 2015. 